\title{
Self Love: A Study of Narcissistic Leadership in Film - Othello and Omkara
}

\author{
Naheed P. Malbari and Dr. Amanat Ali Jalbani \\ SZABIST \\ Karachi, Pakistan
}

\begin{abstract}
In leadership studies, many authors and writers, basically, use examples of real life heroes both historical and contemporary models, yet the impact of fictional characters is underrated. This interdisciplinary study is one such, which fuses many disciplines, namely psychology, social science, literature and cinema and religion into one; and to understand the impact it can have on people. Narcissistic leadership trait is, therefore, the subject of study.

Cinema, both western and eastern, has depicted this element. Shakespeare's plays have often portrayed this concept. Thus, I take Othello and Omkara, the Indian Shakespearean version and show how each director chose to depict this trait of leadership.

Narcissism normally means self-obsession. This complex psychological trait is explained keeping in mind recent published works by many prominent thinkers, both on narcissism as well as on leadership (in other words narcissistic leaders). Yet, Othello or Omkara's obsession with himself and his prowess and judgment as a leader is under scrutiny. The focus is to study narcissism as a trait in a leader and explore this concept further and how cinema depicted this trait rather than to give a psychological judgment on whether both the leaders in the movie had Narcissistic Personality Disorder. Thus, this study is a fusion of many themes and ideas.
\end{abstract}

Keywords: Narcissism, leadership

\section{INTRODUCTION}

A fascinating term, the word leadership can be broken into two; i.e. lead and ship. It simply means that whatever the area of ones work or life, one needs to steer ones course and guide others from rough or unknown waters and steer the ship (or life) to port. Thus, a leader is a mentor and a guide. The leader is someone who can convince others that this is what needs to be done at that particular time and lead them. In other words, a leader is someone who can be trusted to be your knight in shining armor. Narcissism, on the other hand, originated from a Greek myth where Narcissus a vain youth, spent most of his time languishing by the waters, staring at his own reflection in abject self-adoration. It was Freud later, who when describing personality types identified basically three personality traits namely erotic, obsessive and narcissistic where the latter term was given a negative connotation.

This study is not one of psychoanalytical prognosis but one seeing leaders and leadership qualities through the same. Thus, the focus is different.

The researcher wishes to explore the concept of Narcissistic leadership in film and view things with a differing perspective to see the extent to which Shakespeare's main character has influenced others in cinematic representations of both movies and to denote what narcissistic leadership qualities Othello and Omkara have in common and where they differ.

The interdisciplinary, comparative and descriptive study focuses on how film can make the understanding of a complex psychological phenomenon, like narcissism, an understandable trait for the common man.

The paper has been organized as: In section two, a background to both movies will be given followed by a detailed study of Parker's Othello in section three, and in section four, Bharadwaj's Omkara with the concept of narcissistic leadership is analyzed. Finally, study has been concluded in section five.

\section{PARKER'S OTHELLO AND BHARADWAJ'S OMKARA}

Before going into a detailed study of both movies, certain aspects have to be brought to the forefront. Though Parker's Othello more or less takes portions of the main play and the scenes are set in historically true scenario of what Shakespeare had intended, yet it is the characterization of the psychological dilemma, which is to be viewed in both. Leaders need to lead, yet, when each one is riddled with handicaps of their inner demons so as to say, cannot really lead and very often bring about their own downfall as well as destroy a host of other people's life on the way.

Approximately 49 versions of Othello have been made in numerous languages, all depicting the same concept. Yet, the concept of Black Narcissism was most probably first given emphasis in Sergei Yutkevich 1955 Othello. "I start from life," Yutkevich insisted, "Welles from death." In this respect, Yutkevich comes closer to

Journal of Independent Studies and Research (JISR) - Management and Social Sciences \& Economics

Volume 6, Number 2, July 2008 
Shakespeare, emphasizing the free will of characters who determine their own fates rather than any sense of predestination [1].

Parker's Othello has been heavily criticized for moving away from the original and re-enacting scenes and cutting and pasting the dialogue according to what he felt was necessary.

'Critical reaction ranged from mildly positive... to genially dismissive. In Stanley Kauffmann's view, the degree to which Parker successfully transformed this play into a film spelled its downfall as Shakespeare. "I know of no drama in the whole history of art, including the Greeks, which surpass Othello in the sense of a force launched at the start that drives unremittingly to the end, gathering speed and power as it goes" [1].

Omkara, too, has its share of problems; firstly, being a modern adaptation of Othello and set in rural India. In addition, the language used by the director is under great debate, whether it was necessary to use very colorful and foul language and the fact that song and dance sequences were that important in such a dark drama.

However, the point here is not to see the other aspects of the play but to understand whether both directors effectively portrayed narcissism. Using two heavily criticized versions, though Omkara did get rave reviews abroad, this study tries to see to what extent each director could bring forward the main protagonist of the movie to portray such concepts. Is this the story of a leader's rise to power by his own mettle and then tragically be duped by a more cunning and devious person? Do both cinematic presentations depict this simple message or is there something more poignant being stated and how so? Were the director's motives very clear from the onset, and which of the two movies shows the better narcissistic characteristics?

\section{PARKER'S OTHELLO}

Parker called the play in his own words an "erotic thriller". He had felt that previous adaptations though true to Shakespeare's original play lacked the passion, which he felt was central to play. The play is half of the original length, and with a budget of about 11 million, sequences shot in Venice and Rome, and numerous close-up shots and mixed-up scenes not characteristic of many Shakespeare’s films [2].

Yet, it portrays a very tangible Othello played by Fishburne, who displays numerous narcissistic qualities.

"The actor must not only seek ... a 'center' for the Moor; he must create an art object in which every gesture, every vocal and facial sign, confirms the wholeness and meaning of the design. This is the only way Othello can be fully known" [3].

Many have called Fishburne's acting as 'soft-voiced, tentative, and mysteriously uncharismatic performance' [1]. Yet, if one sees the movie from the point of view of narcissism, his performance acquires a different meaning.

The opening sequence on the Venetian waters, a couple in embrace in a gondola, a dark and starry night, the director's use of black and white, a black actor chosen to play Othello namely Fishburne and Swiss born Jacob as the beautiful and white Desdemona, gives the right impact of goodness and evil both entwined in lives of people. A close up scene in the same sequence finds that the dark black character puts on a white mask signifying that the person is trying to hide their true character under a mask or signifying death. One wonders if the director implied that narcissistic leaders often do that.

In the next scene, the Venetian council favors sending of Othello to Cyprus to battle with the Turks, as according to them, no one has the ability to deal with the Turks. This is the first indication of Othello as a trusted and able General who has the Venetian council in thrall for his unique leadership abilities. Many writers are of the opinion that Narcissistic leaders are extremely able and can display strong leadership characteristics.

We next get to see Othello in a silent scene where as a black man he marries the white Desdemona; peering in from the window are Roderigo, who hopes to win the latter; and Iago, played by Branagh, who speaks of certain motives to destroy Othello. It is a chilling scene between both Roderigo and Iago, especially when Iago remarks:

\section{"I am not what I am."}

McGuire says that when Iago declares these lines it announces, 'the fundamental deception in which he cloaks himself throughout the play. To Roderigo, he is a fellow conspirator and a mentor in vice; to Brabantio, he is a dark figure in the night who howls the news of his daughter's elopement; to Othello, he is the trusted subordinate...' [4]. The pauses in the last words send a message to the audience that Iago has a personal grudge and something is definitely up his sleeve to try to destroy Othello. Definitely, in this scene, Iago too portrays not narcissistic but more rightly psychopathic tendencies. Yet, the study is based on Othello's weakness and not Iago's, though the latter plays the most important role in bringing forth latent qualities of Othello to the forefront. 'Healthy narcissism is a mature balanced love of one self coupled with a stable sense of self worth and self-esteem.' One knows one's boundaries and is realistic of ones traits and achievements. On the other hand, 'pathological narcissism involves an impaired, dysfunctional, immature (True) self coupled

Journal of Independent Studies and Research (JISR) - Management and Social Sciences \& Economics Volume 6, Number 2, July 2008 
with a compensatory fiction (the false Self). It depends entirely on 'audience feedback' [5].

Maccoby states that throughout history, it is the narcissists who have inspired people and shaped the world. It is the narcissist who is independent, the innovator, the driving force and aggressively pursues their goals. They are visionaries and have scores of followers. They are what one would call charismatic. Yet, at the same time there is a dark side to all this. Narcissists are extremely sensitive to criticism [6].

The narcissist has no sense of self worth and when Iago invades Othello's mind, the latter is helpless because he has no inner worth and tends to think low of himself. Is it because of his race and the fact that he is a black man in a white society, a black man who is accepted and revered only because of his military prowess?

When Othello confronts Brabantio, the former shows contempt for his father-in law and shows little or no remorse in marrying her against her father's wishes. Brabantio crudely tells Othello what he thinks of him.

\section{“...Run from her guard age to the sooty bosom of} such a thing as thou”

Though Othello was feted in Venice, yet these lines prove what the Venetians really thought of him. Othello will remember words like 'sooty' and 'thing'. Brabantio words portray a racist tinge. In Elizabethan England at that time, the natives of Africa were regarded as 'barbarous, treacherous, libidinous and jealous' [7].

Berry, too, speaks of race as an alienating factor for Othello. It may thus perpetuate and stimulate his sense of worthlessness [8].

Brabantio informs him that he will register a case in the Venetian council, Othello practically ridicules him, sure of himself and the verdict that would be given. Hotchkiss states that narcissistic people lack empathy about the others plight and even if they have hurt anyone they tend to think it is there right. They feel a sense of pleasure. Othello here portrays 'shamelessness' [9]. It matters naught to him that he has advertently hurt Brabantio, when he married the latter's daughter. He has won. That is what is important.

The angry Brabantio asks for justice. The close-up shot shows Othello as angry. Brabantio has not accepted him as the son-in-law and he looks at Brabantio with scorn. Yet, when Othello is pleading his case to the court, he almost immediately changes his tactics and in the most pleasing voice, in a humble manner, relates his side of the story. He calls the court 'noble', 'reverend' and 'approved masters'. The use of such words shows the skill with which both the director and the actor and, of course the playwright, Shakespeare use to their advantage. Othello uses eloquence to get his story across to the Venetians.

All leaders need to be great communicators to get their message across. Covey [10], Welch [11], Kouzes and Posner [12], Fox [13], O Leary [14], and Maxwell [15] are a few who have stressed on this trait.

However, Vaknin calls this quality in narcissists a false modesty. 'It is couched in flourishing phrases...' It is used 'to protect his grandiosity from scrutiny and possible erosion.' It is used to get ones own way and to inflate the Self [5].

When Othello speaks of the their courtship and how his tales of danger had charmed her and made her fall in love with him, the audience can relate to him and one can feel falling into Othello's so called web, the 'charmers who can convert the masses with their rhetoric.' [6]

Narcissists exaggerate accomplishments, talents and skills as they need to feel grandiose and self-important and the unsuspecting person can fall into that trap [5]. However, one can at that point in time sympathize with Othello. The director and actor use a tone that is cajoling if noting else. Fishburne as Othello shows a humbleness that is quite unique. One can feel that he may be a man truly in love.

When Desdemona arrives, she too speaks highly of Othello.

"I saw Othello’s visage in his mind"

Hotchkiss states that narcissists choose those who will look up to them to make them feel all-important and not only recognize, but inflate their ego. Accordingly, the narcissist needs, the 'loved one to be a constant mirror of his or her own worth' [9].

Desdemona looks up to Othello as a knight in shining armor. Freud calls such ardor primary narcissism. Overvaluation is done to recapture primary narcissism [16]. The duke comforts Brabantio speaking highly of Othello. He calls the latter as,

"If virtue no delighted beauty lacks

Your son-in-law is far mare fair than black."

These lines give evidence of Othello as a noble figure, a courageous leader, a respected individual, a person at peace with himself, as he has achieved a lot in his life. Apart from Brabantio's fury, he has never received any impediments in his way to success. His adult life never faced any form of crises and love life too ran as smooth as silk. Yet, Shakespeare himself and the directors have 
emphasized that Othello was very noble. He did secretly court and then marry her. Is that nobility or is it selfcentered ego? It is a paradox.

What Brabantio tells Othello will haunt the latter later on and are repeated oft in Othello's mind. His facade just might crack when his self and ego are put to the test. The seed of suspicion has been sown. Now, all that is needed is for it to bloom.

"Look to her Moor if thou hast eyes to see

She has deceived her father and may thee."

Othello dismisses it by stating,

"My life upon her faith"

Gerard states that Othello never realized that he was 'infringing the mores of Venetian society, the ethical code of Christian behavior, and the sophisticated conventions of polite morality.' He too thinks himself not as a barbarian but as a civilized individual. Othello lacks self-knowledge about just everything [17].

The scene now shifts totally to Iago when Parker, the director, closes in on Iago's face. It is here that the audience comes to know of Iago's plan of 'double knavery,' by using Cassio, and the trust with which Othello holds in Iago. Iago's words "Hell and night must bring this monstrous birth to the world's light" give a foreboding to impending doom. The scene closes in with Iago's face and a chess board, with a black and a white figurine the former depicting Othello, the latter Desdemona and lastly a rider on a horse both white with a lance placed in the center and with lightening all three vanishing. The audience is left to guess who the rider is.

Most would call such implicit trust in a man who has been slighted by Othello himself, as foolhardy. Othello gave the promotion to Cassio rather than Iago. Only a fool would trust a man who has been scorned by you. This is poor leadership on the part of Othello. Iago is the 'infamous aide' and a 'finely drawn, authentic and chilling villain'. Any one who has been passed for promotion would have an axe to grind, and Iago is no different. In every organization such people exist and the wiser leader would usually tell them why and encourage them to 'throw their hats in the ring for the next promotion', and if they are 'simmering with outrage', 'fire them' [18].

They feel that they are master of the universe and can get away with anything. In that, lies their downfall. The relationship of Othello and Iago is such a one.

The night brawl crafted by Iago has two repercussions. Cassio is not only removed from the post of officer but Othello smacks him for awakening his love. For narcissists, everything should be according to their likes and anything wayward is responded with in a highhanded manner. This is the highest form of insult that could be given to a deputy. Othello wants to inflict shame. They tend not to listen to anyone but those who say what they want to hear. Narcissists dislike mentoring. They want their protégés to be reflections of them [6]. Cassio being in a brawl is something Othello cannot stand. He does not ask for Cassio's side of the story but hears what Iago says and gives judgment and harsh punishment.

The director in a close-up sequence of Iago gives the whole game plan of how the dice is to be played. Iago feels he is slighted and Othello's weakness and gullibility is now his greatest weapon. He says,

"Divinity of hell!

When devils will the blackest, sins put on

They do suggest at first with heavenly shows

As I do now..."

He speaks of pouring pestilence into Othello's ear and uses his gullibility to "enmesh them all."

In the next scene, when Iago sees Cassio talking to Desdemona, his five words to Othello change their lives.

"Ha I like not that," is at first dismissed by Othello but when Othello asks what it was he said Iago shrewdly states, "Nothing my lord; or if-I know not what". It is then that Othello's mind starts working overtime and his suspicion arises.

Narcissists consider themselves 'worldly discerning knowledgeable, shrewd, erudite, and astute are actually more gullible than the average person. This is because the narcissist is a fake. His self is false, his life a confabulation, his reality test gone.' The narcissists attract abuse. They tend to provoke anger and hatred as they lack empathy. Successful ones attract erotomaniacs, i.e. mentally ill people who have a fixation on the narcissist and if they are slighted or rebuffed, may turn violent and vindictive [5]. Thus, leaders are most susceptible.

In the next scene when play fighting with Iago, the scene is bright with plenty of sunlight but as Iago begins to darken and poison Othello's mind, the mood of the scene changes too. From bright light, it shifts to the armor room and later to the bedchamber. This light-dark effect is a wondrous example showing how Othello himself becomes the stooge and darkens his mind and soul against his own love. In the scene when Iago and Othello are play fighting, Othello sees Desdemona on the balcony with Emilia and calls out to her in front of Iago,

\footnotetext{
"Excellent wretch! Perdition catch my soul, But I do love thee! And when I love thee not Chaos is come again."
} 
Symbolic words what Othello is revealing is something uncharacteristic, that he is over dependent on Desdemona, that his life before her was totally out of balance, and if anything happens to destroy that, chaos will come again. Gerard speaks about Othello’s superego materializing suddenly. Without someone like Desdemona to continuously give a boast to his ego, his world might come crumbling down [17].

It is this that Iago exploits. Narcissists need to get narcissistic supply; otherwise, they are confused and lost [5]. Hotchkiss speaks of the deadly sins of narcissism including envy, entitlement and bad boundaries. This and the subsequent scene show all these characteristics. Narcissists always need to secure a sense of superiority. The internal balloon, according to her, goes pop when this superiority is in anyway pinched [9].

Othello is a black man and Iago to imply that his wife might be interested in someone else especially a white man is something of an affront to him. He already feels unsure as to why Desdemona had actually married to him. The seed of mistrust and shame and lack of worthiness must already have been there from the beginning. The Venetian has only tolerated him because of his prowess and Othello knows that. He was allowed into their homes only because of his ability and his marriage to Desdemona brought those demons to the forefront, especially when his color and race were ridiculed. Now to be told the same by his trusted Iago does not go too well. His leadership prowess is under question.

'Thus narcissistic envy fueled by desperate need to feel superior is something far darker...it is unconscious and denied, which makes it that much more dangerous' [9].

They feel self-contempt and that is another word for hate. Narcissists have a 'conviction of entitlement.' It is a holdover of an 'egocentric stage of early childhood.' They feel they owe that respect, and if it is not given, they may fly into a threatening rage. If anyone thwarts them, they consider it an insult to their superiority [9]. When Othello questions Cassio's honesty, instead of answering him straight off, Iago repeats the same words disconcerting Othello. Iago speaks of good name in both man and woman implying otherwise. This is not lost on Othello who puts a gun onto Iago asking for the truth. In the closeup shot, Iago's demeanor is unfazed. He speaks of greeneyed jealousy calling it a monster. Blinking a number of times tells us volumes about his state of mind. If such a thing is true then it is a slight on him as a leader. Othello's warped mind readily believes Iago because he thinks it to be true. Once again, the question of race and inferiority complex comes in. Othello's protestations of her innocence are of no consequence. If she can do that to her father, so can she to him. Othello tries to disassociate from
Iago putting distance between himself and Iago. Upset Othello says:

"And yet how nature erring from itself"

The camera focus is on Iago's lips, which go nearer, and nearer to Othello's ear feeding in the poison. The words soon become indistinct. The entire scene shows us that Othello lacks a sense of self. His worth is only if others think him worthy. Others exist to meet their need according to Hotchkiss [9] and Vaknin [5] or not at all. Desdemona met Othello's need. She had chosen Othello, who deep down considered himself unworthy and could only woo her by tales of great adventures. Regarded as his ultimate prize, something never achieved before, to see that slipping away must have been excruciating.

The scene changes but the whispering continues and his own inner demons drag his self worth to its ebb. Narcissists then become depressed and make wrong decisions. 'The narcissist reacts to abuse as would any other victim. Traumatized, he goes through phases of denial, helplessness, rage, depression and acceptance' [5]. His omnipotence has been crudely shattered and he feels humiliated. This form of helplessness is a novel experience.

For the first time, Othello questions marrying Desdemona.

"Oh that we can call these delicate creatures ours

And not their appetites"

Is Othello doubting his sexual prowess? Narcissists can rail against slights true or imagined. They get angry if they do not feel powerful, awe inspiring and intriguing to their partners [5].

Shaking his head, closing his eyes, his imagination runs rife. In his minds eye, he sees her smiling and showing affection for Cassio. Othello crumbles up in pain on the bed holding his head at the perceived injury. The director skillfully shows Iago in the background, who is spying as he had not left the bedchamber but had stayed back to see what effect his whisperings would have. One can feel sorry for him. Yet, Othello has pained himself allowing his imagination to run wild. It is not Desdemona's fault. It is Othello, who choose to hear what Iago had to say. If he had truly loved Desdemona, he would never have allowed the serpent Iago to speak or imply anything against her. However, narcissists do not think like rational people. As Rogers, quoting Lesser, remarks that Iago succeeds in convincing Othello "because the doubts he whispers in Othello's ear are Othello's own" [19].

That night Othello imagines Desdemona sharing her body with Cassio. He awakens from deep sleep. He

Journal of Independent Studies and Research (JISR) - Management and Social Sciences \& Economics

Volume 6, Number 2, July 2008 
imagines himself moving towards the bed and opening the bed curtains to see her smile and lovingly caress Cassio.

\section{"If she be false}

Heaven mocks itself."

Brabantio's warning comes to mind. Rattled, he goes towards the beach. Iago, meanwhile, watches him leave and follows. Othello has now become his pawn.

Othello's tranquil mind is troubled. Othello is violent and wild as spinning magic. Iago implies that she has definitely been unfaithful to Othello. In his extreme anger, Othello tries to drown Iago. Ranting and shouting, Othello wants proof to maintain narcissistic supply. Iago knows that he has already secured the handkerchief from his wife the previous night. Othello had given it to Desdemona as a token of his love. He knows he would use that to plant the final seed. Therefore, he baits Othello by telling him that Cassio in a drunken state had confided of having slept with Desdemona and that he had seen Cassio wipe his beard wuith the handkerchief. Narcissists depict violent rage if they feel slighted or insulted. 'Parker creates a stunning image for that moment when Othello surrenders entirely. We see the two embrace, a physical encounter that means something very different to Othello from Iago. "I am yours," Iago whispers to Othello' [1]. Othello’s dependency is obvious.

Othello soon questions his wife about his handkerchief and that she should bring it to him. Narcissistic men are very possessive. Even a paltry thing like that can descend them into a rage. When Desdemona cannot find it, Othello fears are justified. His smirk and grin are those of a man possessed.

'No longer able to pretend and to suppress their rage, they have it out with the real source of their anger. Then they lose all vestiges of self-control and rave like lunatics. They shout incoherently, make absurd accusations distort facts and air long-suppressed grievances [5].

His narcissistic supply has ended and so his ego has been split. He feels insulted that she considered his gift a worthless trifle.

Next, he asks Iago for news concerning Cassio in a dungeon. Iago affirms that Cassio indeed had slept with his wife and Othello ets an epileptic fit. He graphically visualizes Cassio smirking and making love to his wife. The gullible narcissist is reacting to abuse, as would any other person or victim. 'Traumatized, he goes through the phases of denial, helplessness, rage, depression, and acceptance. But, the narcissist's reactions are amplified by his shattered sense of omnipotence. Abuse breeds humiliation...The narcissistic defense mechanisms and their behavioral manifestations...are useless when confronted with a determined, vindictive, or delusional stalker.' He feels flattered by the attention of the abuser and is, therefore, vulnerable to the manipulation of the stalker [5].

To retrieve his sense of Self, to feel omnipotent, Othello now knows he needs to kill and destroy that which he so loves as he cannot bear the slight given to him. To be cuckolded by a subordinate is a metaphorical death. His reputation would not survive it especially his own 'mythic renown' [20]. Wall indicates that 'Iago's power resides in his ability ...... in making his voice heard, to the exclusion of other, alternate, contrasting voices' [21].

Cornered, he verbally and physically abuses Desdemona in public. This emotional meltdown is the final straw for Othello especially in front of his peers, who had formerly looked up to him. This is his final humiliation as one who formerly had chastised Cassio for losing control. To publicly display, losing control is something he cannot stand; after all, Othello feels he is the embodiment of perfection. He now feels justified in performing the final act, which to him will restore his sense of self and redeem his ego. 'Decomposition leads to acting out and if the abuse is protracted, to withdrawal and even to psychotic micro-episodes' [5].

In the murder scene, he is calm and cool as he enters the bedchamber, though he starts crying seeing her asleep. He justifies the deed he is about to commit and feels omnipotent, omniscient, God like, the avenger, the judge and the executioner all rolled into one.

'.... In putting out "the light," he acts in total darkness' [4].

The darkened bedchamber signifies and hides his darkened soul. Too much brightness would be detrimental to his cause. Harshly he tells her to pray to the Lord. She needs to confess her sin. He speaks of killing her and refuses to hear anything, which she might have to say in her defense. He once again speaks of the handkerchief and when she denies, asks her not to commit perjury. He is now the judge, ready to pronounce the judgment. Narcissists can become psychopathic. Realizing that Cassio is dead and there is no hope for her to prove her innocence, she cries. This is the final farewell insult she can give him for crying for another man. He ruthlessly smothers her with a pillow. The dark and gloomy ambience with Desdemona wearing a white nightgown signifying purity and Othello as usual dressed in black like the devil is characteristically violent. The last caress of Desdemona as she dies is poignant. He cries as she approaches her death. Narcissists, according to Vaknin, do justify their deeds [5].

Journal of Independent Studies and Research (JISR) - Management and Social Sciences \& Economics Volume 6, Number 2, July 2008 
'The act by which Iago moves Othello to murder Desdemona and, thus, destroys himself is essentially intellectual' [4].

Even when the truth is revealed, Othello refuses to take responsibility for his action. He tries to justify his terrible deed and feels that the Venetian court would forgive him. His feelings of grandiose are quite comically portrayed. A misdeed had been done to him. Also, his anger towards Iago, whilst it is natural for being duped, is something that does not sit well with him. He cries like a child near Desdemona's body. In the last speech, he tries to hide his guilt by stating he 'loved not wisely but too well.' He wants to be remembered as a great man. Thus, one can see that narcissistic supply needs to be restored at all costs. Many would state that Othello, killing himself is uncharacteristic of a narcissistic person. Normally, such people rarely, if ever, commit suicide [5]. However, in this case, Othello can only redeem himself by committing this act, as after all he is a soldier.

Thus, he provides for himself suitable punishment for what he now understands to have been the murder of his own wife [7]. As he plunges the dagger, the scene focuses on the man who though once regarded by many, as well as himself as great, is after all indeed very human.

\section{BAHRADWAJ'S OMKARA}

In the Indian movie Omkara, the character Omi represents Othello in Shakespeare's play. The idea of the study is to see whether Bharadwaj's Omi is similar to Parker's Othello.

Vaknin has given a number of criteria for being termed as a narcissistic [5]. Yet, apparently, whether Omkara (Omi) can be called such a person is open for debate because the movie shows conflicting characteristics those, which can be termed as narcissistic, and others, which do not.

Whether Omi had any such characteristics attributed to narcissistic leaders or is he an amalgamation of the 'dark triad' is under focus. Paulhus and Williams use this term to a person defining traits, where people may belong to anyone of the three types namely narcissists, Machiavellians and psychopaths. All may show varying degrees of certain commonalities of behavior at their core such as self-centeredness and aggression, emotional coldness, and social malevolence and duplicity [22].

The study is not one of psychoanalytical prognosis, but one seeing leaders and leadership qualities through the same. Thus, the focus is different.

Omkara, unlike Parker's Othello starts with a scene in bright sunlight. This is very different from the opening scene, full of darkness of Parker's Othello.
We hear a conversation between two men, though a very unusual one at that. The character Langda played by Saif Ali Khan represents the character of Iago. Langda in Hindi means the one with a limp. Sitting on a hilltop with Dolly's fiancé, his first lines reveal the theme of the movie.

"There is a little thread like difference between foolish and bastard person, on one side is foolish, other is of bastard, and if someone pulls the thread then who is foolish and who is bastard is the question of 10 million."

These lines by Langda are very potent and one realizes how he thinks and what he considers others to be like. One feels that these first words will set the mood and theme of the movie. We come to know later that he maybe ironically be stating the relationship between himself and Omkara, the former being considered foolish whilst the latter Omkara is illegitimate and as to who is actually pulling the thread, as to who is the real leader.

We first see Omi in the scene where he is coming to meet Dolly's father. His face is not discernable; he seems to be walking from light to darkness.

Dolly's father, a lawyer, had wanted his daughter to marry someone else. We learn that Omi has apparently kidnapped Dolly literally from her 'mandap' or her ceremonial setup and naturally, the father is upset and comes to kill Omi. The father is stopped by Bhai Sahib, the political guru of both the men and Omkara's mentor.

This scene shows how Omi first shows respect to his to be father-in-law by touching the latter's feet. The father scathingly states that as he had given sanctuary to Omi when he had needed him and Omi has shown his true colors by stealing from his parlor. He ridicules Omi by calling him a half cast but Omi's reaction is to call him 'Kathor' that would mean hard hearted like a beast. Omi's calm attitude, in face of a gun being pointed at him and a smirk when he realizes that the lawyer cannot get his way due to political pressure, is noticeable. The fact that he had kidnapped Dolly on her wedding day and the shame he had cast on her father is of little importance to him. Hotchkiss states that narcissists depict a sense of shamelessness. She calls it one of the seven deadly sins of narcissism. 'In the narcissist, shame is so intolerable that the means have been developed not to experience it at all. What psychologists call "bypassed shame" looks like shamelessness or the absence of a conscience, hiding behind a protective barrier of denial, coldness, blame or rage' [9].

We next see Omi when he is called by Bhai Sahib due to the pleadings of Dolly's father to plead his case that his daughter has been kidnapped against her wishes. Bhai Sahib speaks of Omi’s character. Never has Omi been 
involved with any women or heard any scandal involving any woman. The father feels that his daughter would never have run away with such a man as Omi and he cannot believe she would willfully do such a thing.

"How can I give away my flower like daughter to an evil man? There is difference of caste too."

Omi is half Brahman and his mother is a prostitute.

Just as in Parker's Othello, race was an important issue in Omkara. Both Orkin [7] and Berry [8] had spoken of race as something that alienates, so also Omkara being half-caste and illegitimate to boot may have constituted him feeling left out and alienated by society. One has to understand that caste system plays a very important role in Indian life and to be called half-caste would initiate feelings of worthlessness. Omkara, at all times, tries to project a grandiose image, one that can be used to call him a narcissist [6].

To sustain grandiosity, he did what he had to do, even kill. Nothing could come in his way to having a sense of self worth.

This is not a study on morality or one condoning his lack of morals when he takes up the gun to kill for personal gain. This is, specifically, a study of Narcissistic leaders and not a discourse on what is ethical.

Many may call Omkara as a Machiavellian one who will not stop anyone to stand in their way to power. Goleman says that this type stands as a 'perennial staple of popular entertainment-he's as old as the demon Ravana in the ancient Indian epic the Ramayana...or the charming, yet, callous leader of a criminal gang.' He calls such people 'unscrupulous', 'cunning' who use their 'wile in the service of evil ends' [23].

A close-up shot shows Omi looking forbidding and distant.

"I will present my cut tongue to you if his daughter would call me a liar.",

Dolly comes in red to meet Bhai Sahib, the colors of a bride in Indian community. It may also be a premonition of her own senseless death later on. She speaks as a woman in love who knows of Omkara's background, his life of violence and yet she loves him blindly.

“I am bound by my will. I can't live without Omkara”

Dolly gives her side of the story. By the time she realized her love for Omi, it was too late. She was engaged to someone else and paradoxically Omi is present at her engagement. She later tries to commit suicide. However, she sends a letter to Omi about the same. It is interesting to note that Omkara only rescued her from her loveless marriage when she called for his help. He was not the initiator. This aspect is confusing and confounding as it falls under none of the three triads [22].

In the next scene, Dolly is in darkness on the other side of the road. Her image is only visible through the darkened car windows of her father. The latter stops Omi, pulls down the window and says,

"Beware of woman's trick, when a girl can trick her own father can you expect better from her."

These words, like in the Othello movie, mean the same. A trickster is always a trickster. They will resonate in Omkara's mind later on again and again. The father smiles and smirks as he says these words to Omi who says nothing and just looks peering at him. Omi's silence may reveal much or nothing as the viewer is left to imagine what is going on in Omkara's mind. This is unlike Othello where the former remarked 'my life upon her faith.'

A very crucial factor is the society in which Omkara lived. One has to keep in mind the Hindu culture and religion. Kumari states that according to Hindu religious texts, a woman, by nature, is considered a deceitful and wily creature. The Rig Veda calls a woman as having the hearts of hyenas. She goes on to say that in the Brahma Vaivarta she is regarded as 'hypocritical, recalcitrant and treacherous.' In the Devi Bhagvata she is called as one having the embodiment of 'falsehood, vain, boldness, craftiness, stupidity...impurity...’ [24]

If such attitudes are part of their culture, it is not surprising that Omi has ingrained prejudice against women. His mother too was a prostitute and it only takes a comment by her father to take root in his mind and fester the seed of envy and disbelief.

Farid gives examples of Draupadi, Sita, Shakuntala and Parwati as embodiments of a woman's spirituality and that her greatness is primarily due to her unfailing loyalty to her husband. Their commitment to their husband is unconditional and one has to undergo tremendous sacrifice as a husband has the status of a god and only he could open her road to salvation [25].

Omi, as a political chieftain of a gang of outlaws is in the scene when he is outsmarting a political opponent. He first intimidates the latter by threatening to use an MMS video, which reveals the opponent's nefarious dealings. But, when the man counter attacks by speaking the bet laid on Dolly as having an affair with Omi, the latter calmly gets the opponent killed by the latter's own people and walks off. This shows arrogance and callousness, a narcissistic trait. Omkara then coolly washes his face and 
throws water over his head as if he is washing himself clean of the murder.

Narcissists can be very jealous and cannot bear any slight to their pride or ego or self. If their balloon gets torn by the ill winds of life, they can repair themselves by showing someone else to be inferior' [9].

The man had slighted Dolly and punishment for such an affront was death.

The narcissist is usually hypersensitive and tends to pick up a fight, and feels constantly slighted, injured and insulted. He may have a history of battering or violence offences and behavior [5].

Omi has shown both these traits. His sense of self is supreme, his ego is omnipotent and nobody and nothing should belittle it in any way. To walk away in front of his men from such a thing would be tantamount to being labeled as a coward. His self worth would be shattered.

Later, during the prayer rites, Omi gives the party administrator position to Kesu (Cassio), played by Viveik Oberoi and not Langda, though the latter expected it and had serviced Omi for the last fifteen years. Langda smiles but the audience know he is upset. Omi gives the reason for Langda not being chosen as nothing personal but that as Kesu is young, he has the affection of all the college students, so voting would be one sided. Though Bhai Sahib warns him, yet Omi feels that his judgment is the right one.

As the narcissist becomes increasingly self-assured and thinks he is invincible, he 'listens even less to words of caution and advice. After all, he has been right before when others had their doubts... The result is flagrant risktaking that can lead to catastrophe' [6].

Arrogance is a trait of narcissism [9]. He later strips Kesu of his position over a drunken brawl, as the latter could not hold his drink. This is met with strictest of actions for how could Omkara, be wrong in his judgment of making Kesu as an administrator.

Even productive narcissists are extremely sensitive to criticism or slight and are almost imaginably thinskinned....They cannot tolerate dissent' [6].

They also have distaste for mentoring, as it would be a form of intimacy [6]. Omkara never tells Kesu about his duties or how he should conduct himself. Yet, when Kesu makes a bad judgment and is involved in a brawl, Omkara's anger is evident.

His suspicions are first aroused is, when returning from the station with Langda and Dolly is alone at home, he notices Kesu's bike. Though the relationship of both Kesu and Dolly is entirely innocent, it is Omi who first gets suspicious. With Langda's help, the suspicion is justified. However, he does not ask or find out for himself. It is interesting to note that in Othello, it was Iago who had first put the seed of suspicion; but in Omkara, it is the latter himself who is initially jealous. Omi asks for Langda's opinion, which the latter in the most cunning way gives.

Bharadwaj's uses Shakespeare's play for most of the ideas in the scene and does a very good job of depicting the gullibility of Omi. It is here that he reveals his ingrained mistrust of Dolly.

"Whenever I see you, only one thing comes to mind. Either you are really very innocent or an extremely accomplished whore."

Hotchkiss comes up with an explanation of the concept of envy as one of the seven sins of narcissism. The narcissist needs to feel superior at all times. The intent is to soil the other enough so that the narcissist is restored to a superior position. The feeling of envy will be denied as to admit it would be to acknowledge in an inferior position. Accordingly, 'contempt is usually verbalized but may also be expressed in behavior' [9]. The fact that Omi is speaking to her in such a manner calling her whore is evident that he is desperately trying to reject the envy that is there in his heart.

In the next scene, with Omkara and Langda on the terrace of the house, the latter puts in the poison against Dolly. When Dolly asks for Kesu's pardon part of a marriage gift to her, Omkara is already suspicious. Langda uses that moment to speak of Dolly's extreme partiality towards Kesu. He inquires the reason form Omkara who tells Langda that they both went to college together. Langda's “Oh!!! Therefore," leaving the sentence incomplete, is questioned by Omi. Langda, slapping his head three times, says that his mind is filled with vulgar thoughts. He states that Dolly is extremely beautiful and Kesu is handsome too, so he, Langda, wonders if the two especially Kesu did not have a crush on Dolly. Once again slapping his head, he calls such thoughts disgusting.

It is interesting to note that Omi allows Langda to play in such a way with his emotions. As stated earlier, narcissists are extremely gullible and believe what they want to believe; and therefore, usually become pawns in the hands of psychopaths [5].

In the next few scenes, Dolly's partiality towards Kesu precipitates her own downfall later on.

Langda holds the trump card. A waist bracelet, which was bejeweled and had belonged in Omi’s family, had

Journal of Independent Studies and Research (JISR) - Management and Social Sciences \& Economics

Volume 6, Number 2, July 2008 
been given to Dolly who carelessly left it around to be taken by Langda's wife and given to him. Langda plans to use it for ruining Omi. In a later scene where all the men are having a drunken nightcap, he by the way informs Omi that Kesu had given his girlfriend a beautifully bejeweled waist bracelet. Omkara's suspicions are now very high. Omkara confronts Dolly who cannot find the gift. The scene is set in a darkened room setting the scene for the anger and hatred Omkara develops. He cannot bear that his manhood has been slighted in such a way. In anger, he pulls her hair and strikes her.

Magical thinking is one of the seven deadly sins of narcissism. Narcissists normally depend on 'idealization' and it requires them to be 'centerpieces of the fantasy.' The closet Narcissistic maintains 'their grandiosity and omnipotence through a connection to someone they can pump up. They are masters of the art of flattery and make the most devoted lovers or friends - up until the time when, for whatever reason, they can no longer sustain the illusion of their chosen one's special ness' [9].

His 'gullibility' [5] is evident when though Dolly states that she has no one on whom to bestow such a gift and that she has left the whole world for him; Omi shows no remorse for her plight. He craves empathy from others, especially Langda, as to his plight of being the cuckold but does not return the favor. They know whom they can use, and can become brutally exploitative [6].

This quality is extremely necessary as a leadership style especially in the case of Omkara in scenes when he wants to get political footage in the tumultuous times of political dealings. Yet, this very same flaw is evident in the scene. He shows no remorse for Dolly's plight, the fact that she is all alone and helpless in this new world away from friends and family. That aspect that he has total control over her destiny is what Omkara may have wanted subconsciously in the first place. 'Empathy is the prime inhibitor of human cruelty: withholding our natural inclination to feel with another allows us to treat the other as an It' [23].

Farid [25] giving reference of Kumari [24] states that in Hinduism 'the dependence of woman on man is total and absolute. She dare not break through these bonds of control; otherwise, scripture allows severe punishment. Manu even allows man the liberty of beating his wife if she dares disobey him.'

Omkara striking Dolly is only doing what men are supposed to do. Farid goes on to say that there is intense prejudice against the moral and spiritual worth of woman [25].

In very poignant scene, Omi's narcissistic element is quite evident when he confronts Langda and asks him to reply either yes or no to his question. Omi is shown as having his eyes closed; the scene around him shows rain pouring down as if the heavens are crying. Omi asks only one question four times, which with cunning Langda does not answer. The scene then shifts to killing his opponent for whom they were waiting. After the deed has been done, Omkara hits Langda and again asks the same question four times with yes or no as the only options. Finally, Omi puts a gun in Langda's mouth to try to divulge the answer. Narcissistic leaders only want to hear those messages that confirm their own sense of greatness [5], [6], [9], [23]. They may turn against the bearers of bad news, and therefore, subordinates usually filter out information that confirms only what the narcissist wants to hear [23].

Langda, however, has his personal prerogative here to propel Omkara to his own downfall. So he uses great tactics and insults Omi's leadership abilities, his courage to hear the truth. Omi now asks for proof saying he suspects Langda, as only the latter seems to be having knowledge of such things. No one else seems to even suspect Dolly's infidelity. No one else seems to even suspect Dolly. Langda knows that Omkara is right where he wants him to be. The ball has been thrown in the block hole and Omkara will be stumped.

Just before the wedding in a moving scene, Langda's wife notices the sad look on Dolly's face. Though unmarried, yet she has given herself completely to Omi. She realizes that she can never return home, as according to Indian custom, once a woman has been compromised, her identity and name are soiled until she gains respectability by marrying the man. This helplessness is self-evident. She confides in her friend. Langda's wife gives her some sound advice to ease her plight.

"My grandmother used to say that you should keep your man be a little starving and thirsty. It is important; otherwise, when they are over with you and their cup is full they will spit you like a chewing gum.”

It is important to note that these words suggest that many men are narcissists and the only way to keep a man to ones self is not to give all and keep them guessing.

McGraw speaks about the dark side of men. A particular type, he calls the 'smother brother' who want to control every aspect of the woman's life who they talk to and what to wear etc and that it is best for women to stay away from such men [26]. In other words, he is talking about people with narcissistic tendencies.

On his wedding day, seeing Omis' unhappy expression, Langda's wife goes up to him and asks the matter. Omi tells her that he keeps hearing the voice of Dolly's father in his head that if she could not be faithful to her father, can she ever be faithful to him. She says, 
"You suspect her character don't you? Our own sin has come home to roost in our minds. It is not your fault brother Omi. We leave our houses, relations, love and come into your world with naked hands. Even if we walk through fire then also we are called Betrayers. There is still time. If you still have some sort of doubt, do not come to our house for the wedding. We will keep her."

Kumari [24] and Farid [25] both comment on the religious significance of woman in the Hindu faith. Though Sita passed through fire to prove her innocence, yet she was looked at with suspect. Therefore, if faith suspects women, Langda's wife cannot blame Omi.

However, Omi mind is filled with what he wants to believe. This is an example of narcissistic attitude. Goleman says that such leaders do not seek out information widely. 'They selectively seek on data that supports their views, ignoring and disconfirming facts. They do not listen' [23]. Maccoby also gives the same viewpoint [6].

When Omi sees proof once again orchestrated by Langda, his suspicions are confirmed. It is their wedding night. The scene is set in a darkened room with a swing on which Dolly is sitting. In his warped mind, his suspicions festering for so long have finally been realized. Kesu's girlfriend confronts Kesu of having an affair when she finds the waist bracelet...though Kesu denies, Omi's suspicions have turned true. He comes into the wedding bedchamber and gives Dolly the bracelet. When she asks where he found it, he calls her Kathor and kissing her hand tells her to stop acting innocent. He tells her that she looks innocent even though she has been in bed with Kesu. He, with a pleasing tone, asks her when she had first slept with Kesu, is she with child or has aborted one. He asks her to speak the truth so he will spare her life. Dolly crying tells Omkara not to forgive her. She does not want to live anymore. As in Othello, Omkara smothers her with a nearby pillow.

The difference between the two movies is noticeable here. Desdemona had asked Othello to spare her life for a day and to kill her the following day; while, in Omkara, Dolly asks not to be spared. Knowing Omkara's nature, she knew that asking for life would be of no importance as Omkara was not known to forgive and she has now no reason to live. Indian culture would make it difficult for her to survive after such a scandal and death would be a preferable option.

Omkara soon learns the truth about the waist bracelet and slaps Langda for destroying two lives. Langda sends his wife home and once again tells Omi that he knows only what he knows and that he suspects even his wife for having an affair and that is why she is telling untruths. It seems here that Omkara has lost his will. We no more see him as the aggressor. He does not kill Langda, a surprising fact and instead sings to Dolly. Langda instead is hacked by his wife who apparently drowns herself in a well. Kesu surviving the assault comes to Omi and asks him how he could have suspected him. Omkara trying to once again gain respect of his band of men, who have now come into the room, kills him self for the folly.

Narcissists normally do not kill themselves. It is important to note that narcissists cannot thrive on meaningful relationships due to a deep character flaw in the development of the sense of self. Hotchkiss calls this as the seventh sin, one of bad boundaries [9].

Omkara had seen Dolly as someone wonderful and pure. It seems he is innocent in the ways of the world though a violent criminal himself. For once, he wanted to believe that someone wanted him for himself despite all odds and though he manages to achieve that, his own misgivings and own inferiority complex hampers him to achieve marital bliss. This type of self-fulfilling prophecy of Omkara shows that leaders no matter how high up may very often due to traits within themselves destroy their own lives. Ethical vigilance is extremely important as it safeguard's against manipulators [27]. Its toxicity is not realized until it is too late-and perhaps even never, by those whom it has poisoned [28].

\section{CONCLUSION}

In both movies, the leader at the end killed himself. The study of narcissism does state that such people rarely if ever, commit suicide. Narcissists love themselves too much to do so. However, as being true to the study it was initially based on finding out whether both characters had narcissistic attributes. It was based not on a clinical or pathological dimension to find out if the characters had Narcissistic Personality Disorder. The objective was to analyze leaders who have narcissistic traits.

Both Othello and Omkara display many qualities of narcissism be it according to the Seven Deadly Sins of Hotchkiss or the Nine Diagnostic Criteria in Vaknin's book or the Traits of Maccoby. Both directors depict Narcissism.

A leader's fall from grace is oft the cover stories of books, magazines and movies, of how tragic flaws can ruin their lives. Yet, this is more or less a bedroom drama. What lesson can one learn or for that matter leaders learn from the study of two movies.

It just shows that not only professional lives but also personal ones are equally important. Both are linked. If both aspects of life are sound, leaders rise or achieve great things in this world of ours. This does not mean that 
examples of leaders otherwise are not there. Of course, the world is full with examples of all sorts. The best ones are those who know who they are and have a proper sense of self, both personally and professionally.

It is important for leaders to find their True Self. Only if that is achieved, can they help others become leaders. Othello and Omkara both allowed their narcissism to govern their lives. Instead of developing a healthy form, they allowed the seed of mistrust to enter their minds and lives. Yet, at the end, both the character's vulnerability is obvious not only to the audience of cinema, but also to the characters themselves. It teaches us to not be like them, to know our faults and failings, to know if we, too, are in our way to becoming leaders, are becoming narcissists and finally to know our TRUE SELF. Cinema has a wider audience and as such has the potential to influence many more.

\section{ACKNOWLEDGEMENT}

I would like to thank Dr. Amanat Ali Jalbani for all his help and guidance. I would also like to thank my brother, Cyrus Malbari, for sending me as many books as I needed from the US; my mum, Shernaz Malbari, for all her help and guidance; and my dad, Peshoton, for encouraging me and being proud and happy on my achievements.

\section{REFERENCES}

[1] Brode Douglas, 2000, Shakespeare in the Movies: From Silent Era to Shakespeare in Love, Oxford University Press, Oxford.

[2] Rosenthal Daniel, 2000, Shakespeare on Screen, Hamlyn, Great Britain.

[3] Jorgens Jack J, 1977, Shakespeare on Film, Indiana University Press, USA.

[4] McGuire Philip C., 1973, Othello as an "Assay of Reason", Shakespeare Quarterly, Vol. 24, No. 2, (Spring, 1973).

[5] Vaknin Sam, 2007, Malignant Self Love: Narcissism Revisited, Prague and Skopje, USA.

[6] Maccoby Michael, 2004, Narcissistic Leaders: The Incredible Pros, The Inevitable Cons, Harvard Business Review, Special Issue, Inside the Mind of a Leader, January 2004.

[7] Orkin Martin, 1987, Othello and The "Plain Face" of Racism, Shakespeare Quarterly, Vol. 38, No. 2, (Summer, 1987).
[8] Berry Edward, 1990, Othello's Alienation, USA Studies in English Literature, 1500-1900, Elizabethan and Jacobean Drama, Vol. 30, No. 2.

[9] Hotchkiss Sandy, 2003, Why Is It Always About You: The Seven Deadly Sins of Narcissism, Free Press, New York.

[10]Covey Stephan R. 2004, The $8^{\text {th }}$ Habit: From Effectiveness to Greatness, Simon \& Schuster UK Ltd., UK.

[11] Welch Jack with Welch Suzy, 2005, Winning, Harper Collins Publishers, New York.

[12] Kouzes James M. and Posner Barry Z, 2002, Leadership Challenge, Jossey-Bass, California.

[13]Fox Jeffrey J., 2000, How to Become CEO, Vermilion, London.

[14] O' Leary Colonel Jeff, 2004, The Centurion Principles: Battlefield Lessons for Frontline Leaders, Dorling Kindersley (India), India.

[15] Maxwell John C., 2001, The 21 Most Powerful Minutes in a Leader's Day, Magna Publishing Co Ltd., Mumbai.

[16] Kirsch Arthur, 1978, The Polarization of Erotic Love in "Othello", The Modern Language Review, Vol.73, No. 4. (Oct., 1978), pp. 721- 740.

[17] Gerard Albert, 1957, "Egregiously an Ass”, The Dark Side of the Moor: A View of Othello's Mind, In Shakespeare Survey: An Annual Survey of Shakespearian Study and Production, Vol. 10, 1957.

[18] Whitney John O and Packer Tina, 2001, Power Plays: Shakespeare's Lessons in Leadership and Management, Simon \& Schuster, New York.

[19] Rogers Robert, 1969, Endopsychic Drama in Othello, Shakespeare Quarterly, Vol. 20, No. 2, (Spring, 1969), pp. 205-215.

[20]Bloom Harold, 1998, Shakespeare: The Invention of the Human, The Berkeley Publishing Group, New York.

[21] Wall John N, Shakespeare's Aural Art: The Metaphor of the Ear In Othello, Shakespeare Quarterly, Vol. 30, No. 3, (Summer, 1979), pp. 358-366.

[22] Paulhas Delroy and Williams Kevin, 2002, The Dark Triad of Personality: Narcissism, Machiavellianism, 
and Psychopathy, Journal of Research in Personality 36, No. 6, 2002.

[23] Goleman Daniel, 2006, Social Intelligence, Hutchinson, London.

[24] Kumari Ranjna, 1986, Female Sexuality in Hinduism, Ispck, Delhi .

[25]Farid, Dr. Arifa, 2006, Muslim Women in World Religions' Perspective, University of Karachi, Karachi.

[26] McGraw Dr. Phil, 2006, Love Smart, Simon \& Schuster UK Ltd, London.

[27]Warner Nicholas, 2007, Screening Leadership through Shakespeare: Paradoxes of Leader-Follower Relations in Henry $\mathrm{V}$ on Film, The Leadership Quarterly No. 18, pg 1-15.

[28]Lipman-Blumen J, 2005, The Allure of Toxic Leaders, Oxford University Press, New York. 